\title{
IMPACT OF ROW SPACING AND SOME WEED CONTROL TREATMENTS ON GROWTH, QUALITY AND YIELD OF SUGARCANE
}

(Received:22.3.2010)

\author{
By \\ A.M.A. El-Shafai, *A.A.O. Fakkar and M.A. Bekheet \\ Sugar Crops Research Institute, Agricultural Research Center, Giza, Egypt \\ * Weed Research Central Laboratory, Agricultural Research Center, Giza, Egypt
}

\begin{abstract}
Two field experiments were carried out at Shandaweel Agricultural Research Station, Sohag Governorate in 2007/2008 and 2008/2009 seasons to study the effect of row spacing of sugarcane and some weed treatments on growth, quality and yield. Sugarcane cultiver Phil.8013 was spring-planted in three row spacings of 80,100 and $120 \mathrm{~cm}$, and ten weed control treatments were applied: single application of Garlon $90 \% \mathrm{EC}$ at the rate of $2000 \mathrm{cc} / \mathrm{fed}$ as post-emergence; Brominal $24 \% \mathrm{EC}$ at the rate of $1 \mathrm{l} / \mathrm{fed}$ as post-emergence; Bazagran $48 \% \mathrm{AS}$ at the rate of $1 \mathrm{l} / \mathrm{fed}, 30$ days after planting; Granstar $75 \% \mathrm{DF}$ at the rate of $8 \mathrm{~g} / \mathrm{fed}$ as post-emergence, at 30 days after planting. The application of each of the four herbicides was followed by one hand hoeing 30 days from herbicide application; hand hoeing three times at 25, 45 and 65 days after planting (DAP) and unweeded (control). A split plot design with three replications was used. Row spacings were allocated in the main plots, while weed control treatments were randomly distributed in the sub-plots.

Results revealed that widening spaces between rows of sugarcane from 80 up to 100 and $120 \mathrm{~cm}$ resulted in a significant and gradual increase in dry weight of narrow and broad leaved weeds as well as total weeds $/ \mathrm{m}^{2}$ in both seasons. There was a significant influence of the applied weed treatments on dry weight $/ \mathrm{m}^{2}$ of both narrow and broad-leaved weeds and total weeds $/ \mathrm{m}^{2}$. The results showed that the most effective treatment in eliminating both narrow and broad-leaved weeds was hand hoeing three times, followed by the application of the used herbicides combined with one hand hoeing, and the application of each herbicide alone.

Growing sugarcane in rows spaced at $80-\mathrm{cm}$ apart resulted in a significant increase in stalk height, number of millable canes, cane and sugar yields/fed. The thickest cane stalks were produced from plants grown at $120 \mathrm{~cm}$. Row spacing rows at $100 \mathrm{~cm}$ gave the highest values of brix, sucrose, juice purity and sugar recovery percentages. Practicing hand hoeing three times 25, 45 and 65 DAP to get rid of weeds associated with sugarcane plants resulted in the highest values of the studied traits, while the unweeded plots gave the lowest ones. Under the conditions of the present work, growing sugarcane, in rows spaced at 80 or $100 \mathrm{~cm}$ and controlling accompanied weeds by manual hoeing three times at 25, 45 and 65 DAP, Brominal + hand hoeing once and/or Garlon + hand hoeing once can be recommended for getting the highest cane and sugar yields/fed. Meanwhile, economic evaluation of the studied factors showed that planting sugarcane in rows of $80-\mathrm{cm}$ apart as well as controlling weeds by applying Brominal herbicide + hand hoeing once or manual hoeing three times gave the highest values of net income and profitability $\%$.
\end{abstract}

Key words: growth, quality, row spacing, sugar cane, weed control, yield.

\section{INTRODUCTION}

Row spacing has a direct effect on plant population. It plays a distinct role in the amount of solar radiation intercepted and density, hence, crop canopy development which in turn affects photosynthesis and ultimately the dry matter produced by plant. Also, it may affect cane diameter, length and weight which contribute to cane yield. Avtar et al. (2001) mentioned that sugarcane planted at a row spacing of $75 \mathrm{~cm}$ gave significantly higher cane yield compared to $90 \mathrm{~cm}$ row spacing. El-Geddawy et al. (2002-a) found that narrow row spacing $(100 \mathrm{~cm})$ produced higher number of millable canes, cane and sugar yields compared to 120 and/or $140-\mathrm{cm}$ row spacing. Their results showed that the wider row spacing $(140 \mathrm{~cm})$ significantly recorded thicker stalks, compared with those of narrower spacing of 100 cm. El-Geddawy et al. (2002-b) showed that the widest row spacing gave the highest sucrose, and sugar recovery percentages. Raskar and Bhoi (2003) studied the effect of intra-row spacing (30, 60 or $90 \mathrm{~cm}$ ). and showed that cane girth and number of millable canes were significantly 
higher with a $90-\mathrm{cm}$ intra-row spacing compared with 30 or $60-\mathrm{cm}$ intra-row spacing. Millable cane height and average number of internodes/plant were not significantly affected by spacing. Sundara (2003) grew sugarcane in rows spaced at 90,120 or $150 \mathrm{~cm}$. and found that spacing of 90 $\mathrm{cm}$ resulted in the highest number of stalks at harvest. Juice quality traits were not significantly affected by spacing. Rizk et al. (2004-a) found that sucrose was insignificantly affected by the studied row distances (100, 120 and $140 \mathrm{~cm})$. Rizk et al. (2004-b) showed that the widest row distance significantly gave the thickest stalks. ElShafai and Ismail (2006) planted sugarcane in rows of 80,100 and $120-\mathrm{cm}$ width and found that growing sugarcane in rows of $80-\mathrm{cm}$ apart attained a significant increase in stalk height, number of millable canes, cane and sugar yields/fed. However, stalk diameter increased with $120-\mathrm{cm}$ spacing. Sucrose and sugar recovery percentages were insignificantly affected by row spacing. Singh et al. (2006) found that the highest number of millable canes (128000/ha) and cane yield (62.9 tons/ha) were recorded at $45 \mathrm{~cm}$ spacing followed by $60 \mathrm{~cm}(119400 /$ ha and 58.2 tons/ha) and $75 \mathrm{~cm}$ (112300/ha and 55.0 tons/ha). Ahmed and Khaled (2008) indicated that planting sugarcane in rows spaced at $80 \mathrm{~cm}$ attained significant increases in millable cane length, number of millable cane, cane and sugar yields/fed, compared with 100 and $120 \mathrm{~cm}$ spacings. Total soluble solids, sucrose and sugar recovery percentages were not affected by row spacing.

Ibrahim (1984) indicated that losses up to $40 \%$ of cane yield were caused by weed populations. Ali et al. (1986) found that weed competition decreased millable stalks by $32 \%$ and stalk thickness by $15 \%$. Johnson grass and tall perennial grasses decreased cane yield by $36 \%$ and sugar yield by $31 \%$ compared to weed-free plots. As far as weed control treatments, Singh et al. (2001) revealed that all the herbicides and hand weeding treatments increased cane yield. Attalla and Sogheir (2003) controlled weeds by the application of Metribuzin at $300 \mathrm{~g} / \mathrm{fed}$ at 30 days after planting (DAP); Glufosinate at 2 litre/fed (30 DAP) +2 litre/fed (60 DAP); hand hoeing 4 times (45, 75, 105 and 140 DAP) compared to the untreated plots. They found that hand hoeing 4 times was the best control treatment for broadleaved weeds at 90 and $150 \mathrm{DAP}$, followed by Metribuzin and Glufosinate. They added that hand hoeing 4 times gave the highest yield of sugarcane (49.67 tons/fed), which was higher than the control by $26.71 \%$ in the first season, and by $24.96 \%$ in the second one. Saini et al. (2003) found that hand weeding at 30,60 and 90 DAP had the highest weed control efficiency, where it had the lowest weed population $/ \mathrm{m}^{2}$ and weed dry matter. Meantime, it gave the highest millable canes and cane yield/ha. Singh and Kaur (2003) revealed that three hand hoeings and the application of Sencor $70 \mathrm{WP}$ as pre-emergence followed by $2,4 \mathrm{D}$ (sodium salt $80 \%$ ) as postemergence, each at $2.0 \mathrm{~kg} / \mathrm{ha}$ and Round up at 3.0 litre/ha as post-emergence produced significantly higher cane yield/ha. Raskar (2004) observed significant reduction in weed density and weed dry matter at 120 DAP with the pre-emergence application of Metribuzin $1.5 \mathrm{~kg} / \mathrm{ha}$ supplemented with post emergence application of 2,4 D Na salt 1 $\mathrm{kg} / \mathrm{ha}$. The aforesaid treatment gave the highest cane and commercial cane sugar yields, which were 36.32 and $50.10 \%$ higher than weedy check, respectively. In order of economics, preemergence application of Metribuzin ranked the second. Manuel and Panneerselvam (2005) found that hand hoeing at $30 \mathrm{DAP}$ and Atrazine $(2 \mathrm{~kg}$ ai/ha) were good for controlling all weeds. Singh and Menhi (2008) indicated that plots receiving manual hoeing at 20, 40 and 60 DAP resulted in minimum weed density $\left(58.3 / \mathrm{m}^{2}\right)$ as well as weed dry matter $\left(15.1 \mathrm{~g} / \mathrm{m}^{2}\right)$ and thus proved highly effective. The highest weed control efficiency at 60,90 and 120 DAP worked out to be $42.6,58.5$ and $67.8 \%$, respectively under this treatment. Fakkar et al. (2009) showed that hand hoeing once 45 DAP, hand hoeing twice 45 and 65 DAP and hand hoeing three times 25,45 and 65 DAP, the separate application of herbicides: Triclopyr at the rate of $200 \mathrm{~cm} / \mathrm{fed}$, Florasulam + Flumetsulam at the rate of $30 \mathrm{~cm} / \mathrm{fed}$, Fluroxypyr at the rate of $200 \mathrm{~cm} / \mathrm{fed}$ and Diuron at the rate of $2 \mathrm{~kg} / \mathrm{fed}$, and each of the aforementioned herbicides plus one hand hoeing at 65 DAP had a significant effect on narrow, broad leaved and total weeds. Weed control treatments significantly affected stalk height and diameter, brix, sucrose and sugar recovery percentages as well as millable cans, cane and sugar yields. Using Diuron + one hand hoeing resulted in the highest values of these traits as compared to the unweeded treatment.

The aim of the present work was to find out the best row spacing and the best effective weed treatment to obtain the highest yield and quality of sugarcane.

\section{MATERALS AND METHODS}

Two field experiments were carried out at Shandaweel Agricultural Research Station, Sohag Governorate in 2007/2008 and 2008/2009 to study the effect of row spacing of sugarcane and some weed control treatments on growth, quality and yield of sugarcane. Sugarcane cultivar Phil.8013 was planted in rows spaced at 80,100 and $120 \mathrm{~cm}$. The following weed control treatments were applied: 
1. Garlon $90 \%$ E.C. (Triclopyr) at the rate of $200 \mathrm{cc} / \mathrm{fed}$ as post-emergence, at 30 days after planting.

2. Brominal $24 \%$ EC (Bromoxynil) at the rate of $11 /$ fed as post-emergence, at 30 days after planting.

3. Bazagran $48 \%$ AS (Bentazon) at the rate of 1 1/fed, 30 days after planting.

4. Granstar $75 \%$ DF (Tribenuron-methyl) at the rate of $8 \mathrm{~g} / \mathrm{fed}$ as post-emergence, at 30 days after planting.

5. Garlon followed by hand hoeing once after

30 days from herbicide application.

6. Brominal followed by hand hoeing once after 30 days from herbicide application.

7. Bazagran followed by hand hoeing once after 30 days from herbicide application.

8. Granstar followed by hand hoeing after 30 days from herbicide application.

9. Hand hoeing three times at 25,45 and 65 days after planting.

10. Unweeded (control).

Trade, common and chemical names of the used herbicides are presented in Table (1).

A split plot design with three replications was used. Row spacings were allocated in the main plots, while weed control treatments were randomly distributed in the sub-plots. The subplot area was $60 \mathrm{~m}^{2}$, including 15,12 and 10 rows of $5 \mathrm{~m}$ in length, in case of spacing at 80,100 and $120 \mathrm{~cm}$, respectively. Two rows of three-budded cane cuttings were used in planting of sugarcane on the $25^{\text {th }}$ of March in the $1^{\text {st }}$ season and $15^{\text {th }}$ of March in the $2^{\text {nd }}$ one, and harvested after 12 months in both seasons. The previous cultivated crop was maize followed by fallow. Soil chemical and mechanical analysis of the experimental site showed that the upper $30-\mathrm{cm}$ of the soil was sandy loam which consisted of (56.34 and $51.57 \%$ sand), (28.44 and $26.30 \%$ silt) and (15.22 and $22.13 \%$ clay) and contained (24.0 and 21), (11.7 and 12.2) and (210 and 186) ppm N, P, K with pH of (7.5 and 7.6) in the $1^{\text {st }}$ and $2^{\text {nd }}$ season, respectively. Recommended doses of $\mathrm{P}$ and $\mathrm{K}$ fertilizers were added during seed bed preparation at rates of $30 \mathrm{~kg} \mathrm{P}_{2} \mathrm{O}_{5}$ as calcium super phosphate $15.5 \%$ and $72 \mathrm{~kg} \mathrm{~K}_{2} \mathrm{O}$ as potassium sulphate $48 \%$ $\mathrm{K}_{2} \mathrm{O}$ /fed, respectively, while $\mathrm{N}$ fertilizer was added in the form of Urea $(46.5 \% \mathrm{~N})$ in two equal doses, two months after planting and one month after the $1^{\text {st }}$ one. The other agricultural operations were practiced as recommended by Sugar Crops Research Institute.

\subsection{Recorded data}

\subsubsection{Weed measurements}

Weeds from one $\mathrm{m}^{2}$ in each plot were pulled out after 95 days from planting, separated to broad and narrow leaved weeds and air dried for seven days then oven dried at $70^{\circ} \mathrm{C}$ until a constant weight to record the following items:

1. Dry weight of narrow leaf weeds $\left(\mathrm{g} / \mathrm{m}^{2}\right)$.

2. Dry weight of broad leaf weeds $\left(\mathrm{g} / \mathrm{m}^{2}\right)$.

3. Dry weight of total narrow-and broad leaf weeds $\left(\mathrm{g} / \mathrm{m}^{2}\right)$.

\subsubsection{Sugarcane traits}

At harvest, a sample of 20 stalks from each treatment was taken at random and the following data were recorded:

1. Stalk height $(\mathrm{cm})$.

2. Stalk diameter $(\mathrm{cm})$.

3. Brix $\%$ of juice was determined in laboratory using brix hydrometer.

4. Sucrose $\%$ of juice was determined using sacharemeter according to AOAC (1995).

5. Purity percentage was calculated according to the following equation:

Purity $\%=$ sucrose $\% /$ brix $\%$ x 100

6. Sugar recovery percentage was calculated as follows:

Sugar recovery $\%=$ richness $\%$ x purity $\%$

Richness $=$ (sucrose in $100 \mathrm{~g}$ of juice $\mathrm{x}$ factor) $/ 100$

Factor $=100-[$ fiber $\%+$ physical impurities $\%+$ percent water free from sugar].

Sugar canes of guarded rows were harvested, cleaned, topped to determine:

7. Number of millable canes/fed.

8. Cane yield (ton/fed).

Table(1): Trade, common and chemical names of the herbicides used in the experiment.

\begin{tabular}{|c|c|c|}
\hline Trade name & Common name & Chemical name \\
\hline 1. Garlon $90 \%$ E.C & Triclopyr & $\begin{array}{l}\text { Triclopyr [3,5,6 trichloro-2- pyridyloxy acetic } \\
\text { acid] }\end{array}$ \\
\hline 2. Brominal $24 \% \mathrm{EC}$ & Bromoxynil & $\{3,5$-dibromo-4-hydroxy-benzonitrile $\}$ \\
\hline 3. Bazagran $48 \%$ AS & Bentazon & $\begin{array}{ll}\text { 3-(1-methylethyl)-(1H)-2,1-3 Benzo-thiadiazin- } \\
\text { 4(3H)-one 2,2-(dioxide). }\end{array}$ \\
\hline 4. Granstar $75 \% \mathrm{DF}$ & Tribenuron-methyl & $\begin{array}{l}\text { [Methyl 2-(N- (4-methoxy }-6-\text { methyl }-1,3,5 \\
\text { triazin } 2 \text {-cultivars }[13,14] \text {. Y) methylamine) } \\
\text { caronyl ) amino ) sulful ) benzoate }\end{array}$ \\
\hline
\end{tabular}


9. Sugar yield (ton/fed), which was estimated according to the following equation:

Sugar yield (ton/fed) $=$ cane yield $($ ton/fed) $\mathrm{x}$ sugar recovery $\%$.

The collected data were statistically analyzed according to the method of Snedecor and Cochran (1981).

\subsubsection{Economic evaluation}

Economic evaluation for the results was done to investigate the variations among the different studied combinations to get the highest profitability using some economic criteria. Economic criteria were calculated according to the following formulae described by Buckett (1981):

1. Gross income (total revenue of cane yield) was calculated as formulas:

Gross income = cane yield (ton/fed) $\mathrm{x}$ price of one ton.

2. Net income $(\mathrm{NI})=$ Gross income $(\mathrm{GI})-$ total costs (TC).

3. Profitability $\%=$ NI/TC $\times 100$.

\section{RESULTS AND DISCUSSION}

\subsection{Dry weight of weeds}

Dry weight of narrow, broad-leaved weeds and their total dry weight $/ \mathrm{m}^{2}$ as affected by row spacing of sugarcane, weed control treatments and their interactions, at 95 days after planting are recorded in (Tables 2, 3 and 4). Data revealed that widening spaces between rows of sugarcane from 80 to 100 and $120 \mathrm{~cm}$ resulted in a significant and gradual increase in dry weight of narrow and broad-leaved weeds, as well as, the total weeds $/ \mathrm{m}^{2}$ in both seasons. This result is probably due to the fact that increasing distance between cane rows guaranteed more area, nutrients, water and solar radiation for weed plants to grow well. Moreover, increasing row spacing decreased shading and competition of sugarcane plants with weeds, and hence assured better growth conditions.

Data in Tables (2 and 3) pointed to a significant influence of the applied weed treatments on dry weight $/ \mathrm{m}^{2}$ of both narrow and broad-leaved weeds in the $1^{\text {st }}$ and $2^{\text {nd }}$ seasons. Results in Table 2 manifested that the reduction percentage in dry weight $/ \mathrm{m}^{2}$ of narrow-leaved weeds as affected by the single application of herbicides was 33.1, 29.6, 27.3 and $24.8 \%$ for Garlon, Brominal, Bazagran and Granstar, respectively. However, adding one hoeing to each of these herbicides, raised the values of the reduction percentages to $88.4,88.0,83.5$ and 86.0 $\%$, respectively compared with the control, in the $1^{\text {st }}$ season. These results are in agreement with those mentioned by Manuel and Panneerselvam (2005) and Fakkar et al. (2009).
Thereafter, the following hand hoeing got rid of a large number of later emerged weeds. In the same season, eradication percentage in dry weight of narrow-leaved weeds $/ \mathrm{m}^{2}$ was $92.9 \%$ in the case of practicing three hand hoeings. Similar results were found in the $2^{\text {nd }}$ season. In the same respect, Saini et al. (2003) and Singh and Menhi (2008) found that hand weeding had the highest weed control efficiency and resulted in minimum weed density and weed dry matter.

Data in Table (3) reveal that reduction percentage in dry weight $/ \mathrm{m}^{2}$ of broad-leaved weeds as responded to the single application of Garlon, Brominal, Bazagran and Granstar herbicides was $67.0,66.1,64.5$ and $58.6 \%$. However, following each herbicide treatment with one hoeing raised the reduction percentages to 95.4, 95.1, 94.5 and 94.2.0 \%, respectively, compared with the unweeded plots, in the $1^{\text {st }}$ season. These results are in agreement with those mentioned by Manuel and Panneerselvam (2005) and Fakkar et al. (2009). Meantime, reduction percentage in dry weight of broad-leaved weeds $/ \mathrm{m}^{2}$ was $96.3 \%$ in the case of practicing

three hand hoeings alone. Similar results were recorded in the $2^{\text {nd }}$ season. These results showed the effectiveness of hand hoeing in eliminating both narrow and broad-leaved weeds. These results are in harmony with those reported by Saini et al. (2003) and Singh and Menhi (2008). In addition, it can be noticed that the effectiveness of the used herbicides expressed as reduction percentage was higher in the case of broad-leaved weeds than narrow-leaved ones because these herbicides are recommended mainly for broadleaved weeds.

Results in Table (4) clear that the total dry weight of weeds $/ \mathrm{m}^{2}$ similarly responded to the applied weed control treatments as shown before.

Data in Tables (2, 3 and 4) show that the interaction between row spacing and weed treatments had a significant effect on dry weight $/ \mathrm{m}^{2}$ of narrow and broad leaved weeds and the total dry weight of weeds, in both seasons. It was observed that the lowest values of dry weight of weeds $/ \mathrm{m}^{2}$ were obtained by hoeing weeds manually three times, while allowing weeds to grow freely (control) among rows of sugarcane spaced at $120-\mathrm{cm}$ resulted in the highest dry weight $/ \mathrm{m}^{2}$ in the three cases.

\subsection{Sugarcane characters at harvest time}

\subsubsection{Growth characters (stalk height, diameter and number of millable canes/fed)}

The results showed that increasing row spacing from 80 to 100 and $120 \mathrm{~cm}$ led to a 
Table (2): Dry weight of narrow-leaved weeds $\left(\mathrm{g} / \mathrm{m}^{2}\right)$, as affected by weed treatments, row spacing of sugarcane and their interactions, at 95 days after planting, in $2007 / 2008$ and $2008 / 2009$ seasons

\begin{tabular}{|c|c|c|c|c|c|c|c|c|}
\hline \multirow{3}{*}{$\begin{array}{l}\text { Weed control } \\
\text { treatments }\end{array}$} & \multirow{2}{*}{\multicolumn{4}{|c|}{$2007 / 2008$ season }} & \multicolumn{4}{|c|}{$2008 / 2009$ season } \\
\hline & & & & & \multicolumn{4}{|c|}{ Row spacing } \\
\hline & $\begin{array}{l}\mathbf{8 0} \\
\mathbf{c m}\end{array}$ & $\begin{array}{l}100 \\
\mathrm{~cm}\end{array}$ & $\begin{array}{l}120 \\
\text { cm }\end{array}$ & Mean & $\begin{array}{l}\mathbf{8 0} \\
\mathbf{c m}\end{array}$ & $\begin{array}{l}100 \\
\text { cm }\end{array}$ & $\begin{array}{l}120 \\
\mathrm{~cm}\end{array}$ & Mean \\
\hline Garlon & 219.13 & 235.33 & 329.27 & 261.24 & 218.40 & 227.90 & 236.47 & 227.59 \\
\hline Brominal & 233.17 & 240.87 & 350.83 & 274.96 & 224.93 & 235.07 & 271.23 & 243.74 \\
\hline Bazagran & 231.90 & 249.00 & 370.47 & 283.79 & 229.73 & 247.77 & 286.47 & 254.66 \\
\hline Granstar & 234.77 & 255.47 & 390.97 & 293.73 & 239.03 & 264.23 & 302.43 & 268.57 \\
\hline Garlon and hand hoeing once & 25.30 & 47.27 & 62.33 & 44.97 & 24.57 & 29.33 & 35.03 & 29.64 \\
\hline Brominal and hand hoeing once & 23.40 & 55.50 & 61.33 & 46.74 & 22.03 & 26.50 & 45.20 & 31.24 \\
\hline Bazagran and hand hoeing once & 41.37 & 72.97 & 78.07 & 64.13 & 25.07 & 30.50 & 50.53 & 35.37 \\
\hline Granstar and hand hoeing once & 43.93 & 45.13 & 74.27 & 54.44 & 27.90 & 35.20 & 56.83 & 39.98 \\
\hline Hand hoeing three times & 18.47 & 27.40 & 36.63 & 27.50 & 15.83 & 26.43 & 38.07 & 26.78 \\
\hline Untreated (control) & 260.43 & 385.70 & 525.67 & 390.60 & 295.70 & 442.77 & 547.10 & 428.52 \\
\hline Mean & 133.19 & 161.46 & 227.98 & & 132.32 & 156.57 & 186.94 & \\
\hline $\begin{array}{l}\text { LSD at } 0.05 \text { level for: } \\
\text { Row spacing (A) } \\
\text { Weeding treatments (B) } \\
\text { (A) } \mathrm{x} \text { (B) }\end{array}$ & & & & $\begin{array}{l}3.03 \\
12.53 \\
21.70\end{array}$ & & & & $\begin{array}{l}11.03 \\
13.06 \\
22.63\end{array}$ \\
\hline
\end{tabular}

Table (3): Dry weight of broad-leaved weeds $\left(\mathrm{g} / \mathrm{m}^{2}\right)$, as affected by weed control treatments, row spacing of sugarcane and their interactions, at 95 days after planting, in 2007/2008 and 2008/2009 seasons

\begin{tabular}{|c|c|c|c|c|c|c|c|c|}
\hline \multirow{3}{*}{ Weed control treatments } & \multicolumn{4}{|c|}{ 2007/2008 season } & \multicolumn{4}{|c|}{ 2008/2009 season } \\
\hline & \multicolumn{4}{|c|}{ Row spacing } & \multicolumn{4}{|c|}{ Row spacing } \\
\hline & $\begin{array}{l}80 \\
\text { cm }\end{array}$ & $\begin{array}{l}100 \\
\mathrm{~cm}\end{array}$ & $\begin{array}{l}120 \\
\mathrm{~cm}\end{array}$ & Mean & $\begin{array}{l}80 \\
\text { cm }\end{array}$ & $\begin{array}{l}100 \\
\mathrm{~cm}\end{array}$ & $\begin{array}{l}120 \\
\mathrm{~cm}\end{array}$ & Mean \\
\hline Garlon & 105.00 & 146.70 & 234.00 & 161.90 & 109.20 & 164.93 & 210.50 & 161.54 \\
\hline Brominal & 115.90 & 153.00 & 230.37 & 166.42 & 118.20 & 182.43 & 223.00 & $\mathbf{1 7 4 . 5 4}$ \\
\hline Bazagran & 120.63 & 160.50 & 241.43 & 174.19 & 140.17 & 194.50 & 229.70 & 188.12 \\
\hline Granstar & 125.50 & 170.50 & 313.73 & 203.2 & 175.63 & 207.83 & 249.03 & 210.83 \\
\hline Garlon and hand hoeing once & 16.30 & 23.27 & 28.13 & 22.57 & 35.10 & 54.37 & 61.80 & 50.42 \\
\hline Brominal and hand hoeing once & 17.40 & 22.47 & 31.53 & 23.80 & 38.67 & 59.77 & 45.90 & 48.11 \\
\hline Bazagran and hand hoeing once & 19.57 & 24.67 & 35.87 & 26.70 & 22.20 & 26.67 & 28.77 & 25.88 \\
\hline Granstar and hand hoeing once & 20.57 & 25.90 & 38.63 & 28.37 & 28.87 & 33.07 & 40.90 & 34.28 \\
\hline Hand hoeing three times & 11.13 & 16.40 & 26.93 & 18.16 & 19.30 & 22.20 & 26.63 & 22.71 \\
\hline Untreated (control) & 353.33 & 466.17 & 655.07 & 491.52 & 425.17 & 543.10 & 640.70 & 536.32 \\
\hline Mean & 90.53 & 120.96 & 183.57 & & 111.25 & 148.89 & 175.69 & \\
\hline $\begin{array}{l}\text { LSD at } 0.05 \text { level for: } \\
\text { Row spacing (A) } \\
\text { Weeding treatments (B) } \\
\text { (A) } x(B)\end{array}$ & & & & $\begin{array}{l}16.73 \\
15.76 \\
27.30\end{array}$ & & & & $\begin{array}{l}10.11 \\
12.82 \\
22.20\end{array}$ \\
\hline
\end{tabular}

Table (4): Dry weight of total weeds $\left(\mathrm{g} / \mathrm{m}^{2}\right)$ as affected by weed control treatments, row spacing of sugarcane and their interactions, at 95 days after planting, in 2007/2008 and 2008/2009

\begin{tabular}{|c|c|c|c|c|c|c|c|c|}
\hline \multirow{3}{*}{ Weed control treatments } & \multicolumn{4}{|c|}{$2007 / 2008$ season } & \multicolumn{4}{|c|}{$2008 / 2009$ season } \\
\hline & \multicolumn{4}{|c|}{ Row spacing } & \multicolumn{4}{|c|}{ Row spacing } \\
\hline & $\begin{array}{l}\mathbf{8 0} \\
\mathbf{c m} \\
\end{array}$ & $\begin{array}{l}100 \\
\mathbf{c m}\end{array}$ & $\begin{array}{l}120 \\
\mathrm{~cm} \\
\end{array}$ & Mean & $\begin{array}{l}\mathbf{8 0} \\
\mathbf{c m} \\
\end{array}$ & $\begin{array}{l}100 \\
\mathbf{c m} \\
\end{array}$ & $\begin{array}{l}120 \\
\mathbf{c m} \\
\end{array}$ & Mean \\
\hline Garlon & 324.13 & 382.03 & 563.27 & 423.14 & 327.60 & 392.83 & 446.97 & 389.13 \\
\hline Brominal & 349.07 & 393.87 & 581.20 & 441.38 & 343.13 & 417.50 & 494.23 & 418.29 \\
\hline Bazagran & 352.53 & 409.50 & 611.90 & 457.98 & 369.90 & 442.27 & 516.17 & 442.78 \\
\hline Granstar & 360.27 & 425.97 & 704.70 & 496.98 & 414.67 & 472.07 & 551.47 & 479.40 \\
\hline Garlon and hand hoeing once & 41.60 & 70.53 & 90.47 & 67.53 & 59.67 & 83.70 & 96.83 & 80.07 \\
\hline Brominal and hand hoeing once & 40.80 & 77.97 & 92.87 & 70.54 & 60.70 & 86.27 & 91.10 & 79.36 \\
\hline Bazagran and hand hoeing once & 60.93 & 97.63 & 113.93 & 90.83 & 47.27 & 57.17 & 79.30 & 61.24 \\
\hline Granstar and hand hoeing once & 64.50 & 71.03 & 112.90 & 82.81 & 56.77 & 68.27 & 97.73 & 74.26 \\
\hline Hand hoeing three times & 29.60 & 43.80 & 63.57 & 45.66 & 35.13 & 48.63 & 64.70 & 49.49 \\
\hline Untreated (control) & 613.77 & 851.87 & 1180.7 & 882.12 & 720.87 & 985.87 & 1187.8 & 964.84 \\
\hline Mean & 223.72 & 282.42 & 411.55 & & 243.57 & 305.46 & 362.63 & \\
\hline $\begin{array}{l}\text { LSD at } 0.05 \text { level for: } \\
\text { Row spacing } \quad \text { (A) } \\
\text { Weeding treatments (B) } \\
\text { (A) } \mathrm{x} \text { (B) }\end{array}$ & & & & $\begin{array}{l}19.67 \\
20.70 \\
35.86\end{array}$ & & & & $\begin{array}{l}10.05 \\
18.99 \\
32.89\end{array}$ \\
\hline
\end{tabular}


significant decrease in cane stalk height (Table 5) and number of millable canes/fed (Table 7) as well as an appreciable increase in stalk diameter (Table 6), in the $1^{\text {st }}$ and $2^{\text {nd }}$ seasons. These results could be due to the competition among cane plants grown in narrower rows for growth elements, i.e., nutrients, water and sun light. Chang (1974) explained that the proportion of invisible solar radiation is so much increased than the visible solar radiation due to dense sowing. The former has an elongation effect and hence accounts for the increase in stalk height observed, herein; the decrease in stalk diameter when sugarcane was planted in close spaced rows. The same finding was reported by Mohamed and Ismail (2002), who found that cane stalk height increased, while stalk diameter decreased with decreasing row spacing from 150 to $90 \mathrm{~cm}$. Moreover, Rizk et al. (2004-b) showed that the widest row distance significantly gave the thickest stalks when planting sugarcane in row distances of 100, 120 and $140 \mathrm{~cm}$. Also, El-Shafai and Ismail (2006) obtained the same results when they grew sugarcane in rows spaced at 80, 100 and $120 \mathrm{~cm}$. Moreover, the reduction in

the number of millable canes/fed accompanying the increase in the distance between cane rows could be attributed to that widening distance between rows decreased the density of planted seeds (cane cuttings). This result is in agreement with those mentioned by ElGeddawy et al. (2002-a) and Sundara (2003).

The present results pointed out that cane stalk height and diameter were significantly affected by the used weed control treatments in the $1^{\text {st }}$ and $2^{\text {nd }}$ seasons. The highest values of both stalk characters were obtained by practicing three hand hoeings to get rid of the associated weeds with sugarcane, which decreased weed growth and hence their competition to cane plants. However, the lowest values of the three traits were recorded in the unweeded plots due to the severe competition of weeds with sugarcane plants. These results are in agreement with those found by Ali et al. (1986), Saini et al. (2003) and Fakkar et al. (2009).

Stalk height and diameter were insignificantly influenced by the interaction between row spacing and weed control treatments in both seasons.

3.2.2. Quality characteristics (brix, sucrose, purity and sugar recovery percentages)
The results in Tables (8, 9, 10 and 11) indicate that brix, sucrose, purity and sugar recovery percentages were significantly affected by row spacing of sugarcane in the $1^{\text {st }}$ and $2^{\text {nd }}$ seasons. The results showed that spacing rows of sugarcane at $100 \mathrm{~cm}$ resulted in the highest values of the four quality traits, while the lowest brix and sucrose percentages were recorded by cane stalks grown in rows of $120-\mathrm{cm}$ apart, in both seasons. The same result was obtained for purity $\%$ in the $1^{\text {st }}$ season. However, in the $2^{\text {nd }}$ season, the lowest purity $\%$ was given by canes planted in rows spaced at $80 \mathrm{~cm}$, likewise the lowest sugar recovery \% was given by canes grown in $80-\mathrm{cm}$ rows. Moreover, insignificant variance was noticed between row spacing of 80 and $120 \mathrm{~cm}$ in sucrose, purity and sugar recovery percentages in the $2^{\text {nd }}$ season.

The results in Tables $(8,9,10$ and 11) reveal that the applied weed control treatments had significant effects on brix, sucrose, purity and sugar recovery percentages in the $1^{\text {st }}$ and $2^{\text {nd }}$ seasons. With the exception of purity $\%$ in the $1^{\text {st }}$ season, the highest values of the four traits were obtained by practicing three hand hoeings to get rid of accompanied weeds to sugarcane, which insured the best growth conditions free of weed competition with cane plants, which was positively reflected on more photosynthesis and sugar accumulation in stalks. On the contrary, the lowest values of the studied quality characteristics were given by cane plants suffered from being grown among severe competition with weeds left to grow without any control. Insignificant differences were found in brix $\%$ and sucrose $\%$ as affected by the single application of Garlon and Brominal herbicides and/or each of Bazagran and Granstar followed by one hand hoeing. Also, there were insignificant differences in sugar recovery $\%$ by applying any of the studied herbicides singly. Moreover, insignificant differences were detected in brix, sucrose and sugar recovery percentages in the case of applying each of Garlon and Brominal herbicides followed by hoeing once and practicing three hand hoeings. These results are in line with those stated by Fakkar et al. (2009).

The studied quality traits were insignificantly influenced by the interactions among row spacings and weed control treatments in both seasons.

\subsubsection{Sugarcane yields}

\subsubsection{Cane yield}

Data in Table (12) show that cane yield was significantly affected by row spacing in the $1^{\text {st }}$ and $2^{\text {nd }}$ seasons. The results pointed out that growing sugarcane in rows of $80-\mathrm{cm}$ apart produced 0.61 
Table (5): Stalk height $(\mathrm{cm})$ of sugarcane at harvest, as affected by row spacing, weed control treatments and their interactions in 2007/2008 and 2008/2009 seasons

\begin{tabular}{|c|c|c|c|c|c|c|c|c|}
\hline \multirow{3}{*}{ Treatments } & \multicolumn{4}{|c|}{ 2007/2008 season } & \multicolumn{4}{|c|}{ 2008/2009 season } \\
\hline & \multicolumn{4}{|c|}{ Row spacing } & \multicolumn{4}{|c|}{ Row spacing } \\
\hline & $80 \mathrm{~cm}$ & $100 \mathrm{~m}$ & $120 \mathrm{~cm}$ & Mean & $80 \mathrm{~cm}$ & $100 \mathrm{~cm}$ & $120 \mathrm{~cm}$ & Mean \\
\hline Garlon & 291.67 & 288.33 & 283.67 & 287.89 & 292.67 & 291.67 & 287.33 & 290.56 \\
\hline Brominal & 292.67 & 285.67 & 281.67 & 286.67 & 295.67 & 288.00 & 284.67 & 289.44 \\
\hline Bazagran & 289.33 & 283.00 & 279.67 & 284.00 & 289.00 & 286.00 & 283.67 & 286.22 \\
\hline Granstar & 286.00 & 281.67 & 278.33 & 282.00 & 288.67 & 284.67 & 281.00 & 284.78 \\
\hline Garlon and hand hoeing once & 297.33 & 295.33 & 292.67 & 295.11 & 301.33 & 299.00 & 295.00 & 298.44 \\
\hline Brominal and hand hoeing once & 295.33 & 293.00 & 290.67 & 293.00 & 299.33 & 297.00 & 290.00 & 295.44 \\
\hline Bazagran and hand hoeing once & 294.00 & 290.33 & 285.67 & 290.00 & 297.00 & 295.00 & 288.67 & 293.56 \\
\hline Granstar and hand hoeing once & 293.33 & 288.67 & 283.33 & 288.44 & 296.00 & 292.00 & 29300 & 293.67 \\
\hline Hand hoeing three times & 304.67 & 301.33 & 297.67 & 301.22 & 308.00 & 305.00 & 303.33 & 305.44 \\
\hline Untreated (control) & 284.00 & 277.67 & 275.33 & 279.00 & 287.33 & 281.67 & 277.00 & 282.00 \\
\hline Mean & 292.83 & 288.50 & 284.87 & & 295.50 & 292.00 & 288.37 & \\
\hline $\begin{array}{l}\text { LSD at } 0.05 \text { level for: } \\
\text { Row spacing (A) } \\
\text { Weeding treatments (B) } \\
\text { (A) } \times \text { (B) }\end{array}$ & & & & $\begin{array}{l}0.72 \\
1.94 \\
\text { NS }\end{array}$ & & & & $\begin{array}{l}0.74 \\
2.70 \\
\text { NS }\end{array}$ \\
\hline
\end{tabular}

Table (6): Stalk diameter (cm) of sugarcane at harvest, as affected by row spacing, weed control treatments and their interactions in 2007/2008 and 2008/2009 seasons

\begin{tabular}{|c|c|c|c|c|c|c|c|c|}
\hline \multirow{3}{*}{ Treatments } & \multicolumn{4}{|c|}{ 2007/2008 season } & \multicolumn{4}{|c|}{ 2008/2009 season } \\
\hline & \multicolumn{4}{|c|}{ Row spacing } & \multicolumn{4}{|c|}{ Row spacing } \\
\hline & $80 \mathrm{~cm}$ & $100 \mathrm{~cm}$ & $120 \mathrm{~cm}$ & Mean & $80 \mathrm{~cm}$ & $100 \mathrm{~cm}$ & $120 \mathrm{~m}$ & Mean \\
\hline Garlon & 2.64 & 2.67 & 2.73 & 2.68 & 2.66 & 2.62 & 2.67 & 2.65 \\
\hline Brominal & 2.65 & 2.68 & 2.71 & 2.68 & 2.67 & 2.70 & 2.75 & 2.71 \\
\hline Bazagran & 2.59 & 2.62 & 2.69 & 2.64 & 2.62 & 2.70 & 2.73 & 2.68 \\
\hline Granstar & 2.55 & 2.61 & 2.71 & 2.62 & 2.59 & 2.63 & 2.76 & 2.66 \\
\hline Garlon and hand hoeing once & 2.61 & 2.72 & 2.78 & 2.70 & 2.65 & 2.73 & 2.80 & 2.73 \\
\hline Brominal and hand hoeing once & 2.63 & 2.69 & 2.75 & 2.69 & 2.68 & 2.72 & 2.78 & 2.73 \\
\hline Bazagran and hand hoeing once & 2.61 & 2.66 & 2.71 & 2.66 & 2.64 & 2.71 & 2.75 & 2.70 \\
\hline Granstar and hand hoeing once & 2.59 & 2.62 & 2.73 & 2.65 & 2.62 & 2.68 & 2.80 & 2.70 \\
\hline Hand hoeing three times & 2.64 & 2.72 & 2.79 & 2.72 & 2.65 & 2.69 & 2.83 & 2.72 \\
\hline Untreated (control) & 2.41 & 2.50 & 2.55 & 2.49 & 2.48 & 2.66 & 2.60 & 2.58 \\
\hline Mean & 2.59 & 2.65 & 2.71 & & 2.63 & 2.68 & 2.75 & \\
\hline $\begin{array}{l}\text { LSD at } 0.05 \text { level for: } \\
\text { Row spacing }\end{array}$ & & & & 0.04 & & & & 003 \\
\hline Weeding treatments (B) & & & & 0.04 & & & & 0.06 \\
\hline (A) $x(B)$ & & & & NS & & & & NS \\
\hline
\end{tabular}

Table (7): Number of millable canes (thousand/fed) at harvest, as affected by row spacing, weed control treatments and their interactions in $2007 / 2008$ and $2008 / 2009$ seasons

\begin{tabular}{|c|c|c|c|c|c|c|c|c|}
\hline \multirow{3}{*}{ Treatments } & \multicolumn{4}{|c|}{ 2007/2008 season } & \multicolumn{4}{|c|}{ 2008/2009 season } \\
\hline & \multicolumn{4}{|c|}{ Row spacing } & \multicolumn{4}{|c|}{ Row spacing } \\
\hline & $80 \mathrm{~cm}$ & $100 \mathrm{~cm}$ & $120 \mathrm{~cm}$ & Mean & $80 \mathrm{~cm}$ & $100 \mathrm{~cm}$ & $120 \mathrm{~cm}$ & Mean \\
\hline Garlon & 51.39 & 49.15 & 47.68 & 49.41 & 52.56 & 50.53 & 49.10 & 50.73 \\
\hline Brominal & 50.56 & 47.93 & 46.21 & 48.23 & 51.51 & 49.55 & 47.15 & 49.40 \\
\hline Bazagran & 49.76 & 47.57 & 44.67 & 47.33 & 49.70 & 47.10 & 46.29 & 47.70 \\
\hline Granstar & 48.31 & 47.61 & 45.28 & 47.07 & 47.79 & 46.19 & 46.48 & 46.82 \\
\hline Garlon and hand hoeing once & 52.57 & 51.36 & 46.85 & 50.26 & 50.23 & 51.24 & 48.67 & 50.71 \\
\hline Brominal and hand hoeing once & 52.84 & 52.99 & 49.97 & 51.94 & 52.29 & 51.84 & 49.85 & 51.33 \\
\hline Bazagran and hand hoeing once & 51.66 & 50.86 & 46.87 & 49.80 & 51.90 & 50.71 & 47.12 & 49.91 \\
\hline Granstar and hand hoeing once & 51.87 & 49.09 & 47.04 & 49.33 & 52.41 & 49.47 & 46.59 & 49.49 \\
\hline Hand hoeing three times & 54.74 & 52.86 & 50.37 & 52.65 & 52.65 & 53.04 & 50.69 & 52.13 \\
\hline Untreated (control) & 44.45 & 43.58 & 41.64 & 43.22 & 44.58 & 44.13 & 40.58 & 43.09 \\
\hline Mean & 50.81 & 49.30 & 46.66 & & 50.76 & 49.38 & 47.25 & \\
\hline $\begin{array}{l}\text { LSD at } 0.05 \text { level for: } \\
\text { Row spacing } \quad \text { (A) } \\
\text { Weeding treatments (B) } \\
\text { (A) x (B) }\end{array}$ & & & & $\begin{array}{l}1.11 \\
1.08 \\
\text { NS }\end{array}$ & & & & $\begin{array}{l}0.89 \\
1.07 \\
\text { NS }\end{array}$ \\
\hline
\end{tabular}


Table (8): Brix \% of sugarcane juice at harvest, as affected by row spacing, weed control treatments and their interactions in 2007/2008 and 2008/2009 seasons

\begin{tabular}{|c|c|c|c|c|c|c|c|c|}
\hline \multirow{3}{*}{ Treatments } & \multirow{2}{*}{\multicolumn{4}{|c|}{$\begin{array}{c}2007 / 2008 \text { season } \\
\text { Row spacing }\end{array}$}} & \multicolumn{4}{|c|}{ 2008/2009 season } \\
\hline & & & & & \multicolumn{4}{|c|}{ Row spacing } \\
\hline & $\begin{array}{l}80 \\
\mathrm{~cm}\end{array}$ & $\begin{array}{l}100 \\
\mathrm{~cm} \\
\end{array}$ & $\begin{array}{l}120 \\
\mathrm{~cm} \\
\end{array}$ & Mean & $\begin{array}{l}80 \\
\mathrm{~cm}\end{array}$ & $\begin{array}{l}100 \\
\mathrm{~cm}\end{array}$ & $\begin{array}{l}120 \\
\mathrm{~cm} \\
\end{array}$ & Mean \\
\hline Garlon & 19.67 & 20.05 & 19.60 & 19.77 & 19.87 & 20.07 & 19.82 & 19.92 \\
\hline Brominal & 19.72 & 20.07 & 19.67 & 19.82 & 20.02 & 20.15 & 19.83 & 20.00 \\
\hline Bazagran & 19.63 & 19.99 & 19.58 & 19.74 & 19.75 & 19.87 & 19.60 & 19.74 \\
\hline Granstar & 19.57 & 19.87 & 19.52 & 19.65 & 19.68 & 19.78 & 19.67 & 19.71 \\
\hline Garlon and hand hoeing once & 19.97 & 20.15 & 19.86 & 19.99 & 20.23 & 20.37 & 20.07 & 20.22 \\
\hline Brominal and hand hoeing once & 20.00 & 20.23 & 19.90 & 20.04 & 20.25 & 20.50 & 20.12 & 20.29 \\
\hline Bazagran and hand hoeing once & 19.78 & 20.10 & 19.75 & 19.88 & 19.95 & 20.03 & 19.87 & 19.95 \\
\hline Granstar and hand hoeing once & 19.72 & 20.10 & 19.65 & 19.82 & 19.87 & 19.88 & 19.72 & 19.82 \\
\hline Hand hoeing three times & 20.07 & 20.27 & 19.87 & 20.07 & 20.43 & 20.55 & 20.17 & 20.38 \\
\hline Untreated (control) & 15.73 & 15.83 & 15.57 & 15.71 & 16.02 & 16.12 & 15.85 & 15.99 \\
\hline Mean & 19.39 & 19.67 & 19.30 & & 19.61 & 19.73 & 19.47 & \\
\hline $\begin{array}{l}\text { LSD at } 0.05 \text { level for: } \\
\text { Row spacing (A) } \\
\text { Weeding treatments (B) } \\
\text { (A) } x(B)\end{array}$ & & & & $\begin{array}{l}0.10 \\
0.13 \\
\text { NS }\end{array}$ & & & & $\begin{array}{c}0.04 \\
0.17 \\
\text { NS }\end{array}$ \\
\hline
\end{tabular}

Table (9): Sucrose\% of sugarcane at harvest, as affected by row spacing, weed control treatments and their interactions in 2007/2008 and 2008/2009 seasons

\begin{tabular}{|c|c|c|c|c|c|c|c|c|}
\hline \multirow{3}{*}{ Treatments } & \multicolumn{4}{|c|}{ 2007/2008 season } & \multicolumn{4}{|c|}{ 2008/2009 szeason } \\
\hline & \multicolumn{4}{|c|}{ Row spacing } & \multicolumn{4}{|c|}{ Row spacing } \\
\hline & $80 \mathrm{~cm}$ & $100 \mathrm{~cm}$ & $120 \mathrm{~m}$ & Mean & $80 \mathrm{~cm}$ & $100 \mathrm{~m}$ & $120 \mathrm{~cm}$ & Mean \\
\hline Garlon & 17.88 & 18.40 & 17.64 & 17.97 & 18.06 & 18.33 & 18.12 & 18.17 \\
\hline Brominal & 17.93 & 18.41 & 17.71 & 18.01 & 18.23 & 18.63 & 18.18 & 18.35 \\
\hline Bazagran & 17.82 & 18.11 & 17.62 & 17.85 & 18.02 & 18.18 & 17.97 & 18.06 \\
\hline Granstar & 17.73 & 18.23 & 17.74 & $\mathbf{1 7 . 9 0}$ & 18.00 & 18.13 & 18.03 & 18.05 \\
\hline Garlon and hand hoeing once & 18.37 & 18.49 & 18.07 & 18.31 & 18.47 & 18.82 & 18.58 & 18.62 \\
\hline Brominal and hand hoeing once & 18.39 & 18.54 & 18.17 & 18.37 & 18.53 & 18.02 & 18.55 & 18.70 \\
\hline Bazagran and hand hoeing once & 18.06 & 18.37 & 17.79 & 18.07 & 18.29 & 18.56 & 18.18 & 18.34 \\
\hline Granstar and hand hoeing once & 17.91 & 18.44 & 17.79 & 18.05 & 18.28 & 18.23 & 18.02 & 18.18 \\
\hline Hand hoeing three times & 18.11 & 18.52 & 18.29 & 18.31 & 18.85 & 18.93 & 18.70 & 18.83 \\
\hline Untreated (control) & 13.94 & 13.94 & 13.61 & 13.83 & 13.98 & 14.38 & 13.90 & 14.09 \\
\hline Mean & 17.61 & $\mathbf{1 7 . 9 5}$ & 17.44 & & $\mathbf{1 7 . 8 7}$ & 18.12 & $\mathbf{1 7 . 8 2}$ & \\
\hline \multicolumn{9}{|l|}{ LSD at 0.05 level for: } \\
\hline Weeding treatments (B) & & & & 0.20 & & & & 0.24 \\
\hline (A) $x(\mathrm{~B})$ & & & & NS & & & & NS \\
\hline
\end{tabular}

Table (10): Juice purity \% of sugarcane at harvest, as affected by row spacing, weed control treatments and their interactions in 2007/2008 and 2008/2009 seasons

\begin{tabular}{|c|c|c|c|c|c|c|c|c|}
\hline \multirow{3}{*}{ Treatments } & \multicolumn{4}{|c|}{ 2007/2008 season } & \multicolumn{4}{|c|}{ 2008/2009 season } \\
\hline & \multicolumn{4}{|c|}{ Row spacing } & \multicolumn{4}{|c|}{ Row spacing } \\
\hline & $80 \mathrm{~cm}$ & $100 \mathrm{~cm}$ & $120 \mathrm{~m}$ & Mean & $80 \mathrm{~cm}$ & $100 \mathrm{~cm}$ & $120 \mathrm{~cm}$ & Mean \\
\hline Garlon & 83.99 & 84.65 & 83.21 & 83.95 & 83.93 & 84.30 & 84.43 & 84.22 \\
\hline Brominal & 84.00 & 84.62 & 83.19 & 83.94 & 84.08 & 85.30 & 84.63 & 84.67 \\
\hline Bazagran & 83.90 & 83.63 & 83.19 & 83.57 & 84.28 & 84.50 & 84.77 & 84.52 \\
\hline Granstar & 83.78 & 84.73 & 84.06 & 84.19 & 84.52 & 84.65 & 84.72 & 84.63 \\
\hline Garlon and hand hoeing once & 84.93 & 84.63 & 84.00 & 84.52 & 84.16 & 85.17 & 85.47 & 84.93 \\
\hline Brominal and hand hoeing once & 84.86 & 84.46 & 84.34 & 84.55 & 84.36 & 85.43 & 85.08 & 84.96 \\
\hline Bazagran and hand hoeing once & 84.33 & 84.31 & 83.21 & 83.95 & 84.59 & 85.49 & 84.50 & 84.86 \\
\hline Granstar and hand hoeing once & 83.94 & 84.94 & 83.67 & 84.19 & 84.99 & 84.67 & 84.44 & 84.70 \\
\hline Hand hoeing three times & 83.25 & 84.25 & 85.02 & 84.17 & 84.97 & 84.83 & 85.52 & 85.11 \\
\hline Untreated (control) & 83.21 & 82.69 & 81.11 & 82.34 & 81.86 & 83.72 & 82.32 & 82.64 \\
\hline Mean & 84.02 & 84.29 & 83.50 & & 84.17 & 84.81 & 84.59 & \\
\hline \multicolumn{9}{|l|}{ LSD at 0.05 level for: } \\
\hline Row spacing $\quad$ (A) & & & & 0.45 & & & & 0.43 \\
\hline $\begin{array}{l}\text { Weeding treatments (B) } \\
\text { (A) } \mathrm{x}(\mathrm{B})\end{array}$ & & & & $\begin{array}{l}0.71 \\
\text { NS }\end{array}$ & & & & $\begin{array}{l}0.89 \\
\text { NS }\end{array}$ \\
\hline
\end{tabular}


and 3.76 ton of canes/fed higher than that obtained by planting it in rows spaced at 100 and $120 \mathrm{~cm}$, in the $1^{\text {st }}$ season, respectively corresponding to 1.45 and 4.03 ton/fed, in the $2^{\text {nd }}$ one. These results could be attributed to the increase in number of millable canes/fed as row spacing decreased (Table 7). These results are in agreement with those reported by El-Shafai and Ismail (2006) and Ahmed and Khaled (2008). Meanwhile, insignificant variance in cane yield/fed was found between 80 and $100-\mathrm{cm}$ row spacing, in the $1^{\text {st }}$ season.

The results pointed to a significant response of cane yield/fed due to the applied weed control treatments in the $1^{s t}$ and $2^{\text {nd }}$ seasons. In the $1^{s t}$ one, controlling weeds with Garlon, Brominal, Bazagran and Granstar alone increased cane yield by $6.32,5.77,4.53$ and 3.64 tons/fed, successively, compared with the unweeded plots. Meantime, the addition of one hand hoeing to each of the used herbicides, in the same order, raised the productivity of one feddan to 8.60 , 9.76, 6.54 and 7.16 tons of canes. Moreover, hoeing weeds manually three times eradicated weeds to a large extent and resulted in getting the highest increase in cane yield (10.96 tons/fed), compared to the control, which produced the lowest cane yield/fed. Similar results were observed in the $2^{\text {nd }}$ season. These results manifested the importance of hand hoeing as an effective means in getting rid of weeds that compete with sugarcane plants. These results are in line with those given by Singh et al.(2001), Attalla and Sogheir (2003), Saini et al. (2003) and Fakkar et al. (2009).

The interactions among row spacings and weed control treatments had insignificant effect on cane yield in both seasons.

\subsubsection{Sugar yield}

Data in Table (13) indicate that sugar yield was significantly influenced by row spacing in the $1^{\text {st }}$ and $2^{\text {nd }}$ seasons. In the $1^{\text {st }}$ one, it was found that planting sugarcane in rows spaced at 80 and $100-\mathrm{cm}$ apart increased sugar yield by 0.50 and 0.56 ton/fed, compared with that grown in rows of $120 \mathrm{~cm}$, respectively, corresponding to 0.44 and 0.40 ton sugar/fed, in the $2^{\text {nd }}$ season. Meantime, the difference between 80 and $100 \mathrm{~cm}$ in their effect on sugar yield was insignificant in both seasons. These results are in agreement with those reported by El-Shafai and Ismail (2006) and Ahmed and Khaled (2008). The results exhibited a significant effect on sugar yield due to the used weed control treatments in both seasons. In the $1^{\text {st }}$ one, the single application of Garlon, Brominal, Bazagran and Granstar resulted in 2.03, 1.98
, 1.76 and 1.72 ton of sugar/fed higher than the unweeded plots, respectively. Moreover, combining each of the used herbicides with one hand hoeing following its application recorded $1.44,2.59,2.08$ and 2.17 tons of sugar/fed, in the same respect. Based on the obtained results of growth, quality and cane yield presented in the previous Tables, practicing three hand hoeings to control weeds resulted in the production of the highest increase in sugar yield (2.68 tons/fed) compared to the control, which produced the lowest sugar yield/fed. Similar trend was recorded in the $2^{\text {nd }}$ season. These results are in agreement with those found by Ali et al. (1986) and Fakkar et al. (2009).

Sugar yield was insignificantly affected by the interactions among row spacings and weed control treatments in both seasons.

\subsection{Economic evaluation}

Data in Table(14) show that the average total cost was L.E. $7142 \mathrm{fed}^{-1}$ for fixed cost (land rent, seed bed preparation, planting, post planting practices, i.e. fertilization, irrigation, insect control and harvesting) in 2007/08 and 2008/09 seasons. The average variable cost was L.E. 180, 120, 90, 80 and $40 \mathrm{fed}^{-1}$ for weed control by one hand hoeing, Garlon, Brominal, Bazagran and Granestar, respectively. The price of one ton of canes was L.E 234.5 in both seasons. The results cleared that the average net return was the highest in case of growing sugarcane in rows spaced at 80 $\mathrm{cm}$ (L.E. 5553.83), which attained L.E. 241.53 and 1113.38 higher than those gained when sugarcane was planted in rows of 100 and $120-\mathrm{cm}$ apart.

As for the net income resulted from the application of the ten weed control treatments, the results indicated that the controlling weeds by Brominal herbicides + hand hoeing once (LE. 5835.79), which was approximately equal to manual hoeing three times (LE. 5833.12), while Garlon herbicide + hand hoeing once ranked the third (LE. 5518.53). The lowest net income was recorded when weeds left to grow without any control whether sugarcane was grown at any of the three row spacing.

Concerning the profitability corresponded to the studied factors, data in Table (14) manifest that decreasing row width from 120 to 100 and 80 $\mathrm{cm}$ led to an increase in profitability $\%$.

Meantime, the highest profitability \% (80.83) was recorded by Brominal herbicides + hand hoeing once followed by three manual hoeings. However, unweeding (control) resulted in the lowest profitability $(55.60 \%)$ compared with the other weed control treatments. 
Table (11): Sugar recovery \% of sugarcane at harvest, as affected by row spacing, weed control treatments and their interactions in 2007/2008 and 2008/2009 seasons

\begin{tabular}{|c|c|c|c|c|c|c|c|c|}
\hline \multirow{3}{*}{ Treatments } & \multicolumn{4}{|c|}{$2007 / 2008$ season } & \multicolumn{4}{|c|}{ 2008/2009 season } \\
\hline & \multicolumn{4}{|c|}{ Row spacing } & \multicolumn{4}{|c|}{ Row spacing } \\
\hline & $80 \mathrm{~cm}$ & $100 \mathrm{~cm}$ & $120 \mathrm{~cm}$ & Mean & $80 \mathrm{~cm}$ & $100 \mathrm{~m}$ & $120 \mathrm{~m}$ & Mean \\
\hline Garlon & 11.24 & 11.64 & 10.99 & 11.29 & 11.34 & 11.55 & 11.44 & 11.44 \\
\hline Brominal & 11.27 & 11.64 & 11.03 & 11.31 & 11.46 & 11.87 & 11.51 & 11.62 \\
\hline Bazagran & 11.20 & 11.33 & 10.98 & 11.17 & 11.36 & 11.49 & 11.41 & 11.42 \\
\hline Granstar & 11.12 & 11.56 & 11.17 & 11.28 & 11.39 & 11.48 & 11.44 & 11.44 \\
\hline Garlon and hand hoeing once & 11.67 & 11.69 & 11.35 & 11.57 & 11.61 & 11.96 & 11.88 & 11.82 \\
\hline Brominal and hand hoeing once & 11.67 & 11.70 & 11.47 & 11.61 & 11.67 & 12.12 & 11.80 & 11.86 \\
\hline Bazagran and hand hoeing once & 11.40 & 11.58 & 11.08 & 11.35 & 11.57 & 11.86 & 11.49 & 11.64 \\
\hline Granstar and hand hoeing once & 11.25 & 11.75 & 11.14 & 11.38 & 11.62 & 11.55 & 11.39 & 11.52 \\
\hline Hand hoeing three times & 11.26 & 11.65 & 11.64 & 11.52 & 11.95 & 11.98 & 11.95 & 11.96 \\
\hline Untreated (control) & 8.82 & 8.77 & 8.29 & 8.63 & 8.69 & 9.15 & 8.70 & 8.85 \\
\hline Mean & 11.09 & 11.33 & 10.91 & & 11.27 & 11.50 & 11.30 & \\
\hline \multicolumn{9}{|l|}{ LSD at 0.05 level for: } \\
\hline $\begin{array}{l}\text { Row spacing } \\
\text { Weeding treatments (B) }\end{array}$ & & & & $\begin{array}{l}0.17 \\
0.19\end{array}$ & & & & $\begin{array}{l}0.13 \\
0.25\end{array}$ \\
\hline (A) $x(B)$ & & & & NS & & & & NS \\
\hline
\end{tabular}

Table (12): Cane yield (ton/fed) at harvest, as affected by row spacing, weed control treatments and their interactions in 2007/2008 and 2008/2009 seasons

\begin{tabular}{|c|c|c|c|c|c|c|c|c|}
\hline \multirow{3}{*}{ Treatments } & \multicolumn{4}{|c|}{ 2007/2008 season } & \multicolumn{4}{|c|}{$2008 / 2009$ season } \\
\hline & \multicolumn{4}{|c|}{ Row spacing } & \multicolumn{4}{|c|}{ Row spacing } \\
\hline & $\begin{array}{l}80 \\
\mathrm{~cm}\end{array}$ & $\begin{array}{l}100 \\
\mathrm{~cm}\end{array}$ & $\begin{array}{l}120 \\
\mathrm{~cm}\end{array}$ & Mean & $\begin{array}{l}80 \\
\mathrm{~cm}\end{array}$ & $\begin{array}{l}100 \\
\mathrm{~cm}\end{array}$ & $\begin{array}{l}120 \\
\mathrm{~cm}\end{array}$ & Mean \\
\hline Garlon & 53.39 & 53.65 & 50.03 & 52.36 & 56.16 & 54.80 & 50.97 & 53.98 \\
\hline Brominal & 53.77 & 52.43 & 49.23 & 51.81 & 54.30 & 52.61 & 49.92 & 52.28 \\
\hline Bazagran & 52.62 & 51.75 & 47.35 & $\mathbf{5 0 . 5 7}$ & 53.14 & 51.12 & 49.08 & 51.11 \\
\hline Granstar & 51.18 & 50.17 & 47.69 & 49.68 & 51.36 & 50.43 & 48.34 & 50.05 \\
\hline Garlon and hand hoeing once & 56.56 & 54.86 & 52.50 & 54.64 & 56.69 & 54.44 & 51.63 & 54.26 \\
\hline Brominal and hand hoeing once & 56.54 & 56.66 & 54.22 & 55.80 & 56.50 & 56.58 & 53.57 & 55.55 \\
\hline Bazagran and hand hoeing once & 54.51 & 53.69 & 49.55 & 52.58 & 56.27 & 54.58 & 51.29 & 54.05 \\
\hline Granstar and hand hoeing once & 55.37 & 53.59 & 50.63 & 53.20 & 56.52 & 53.05 & 50.12 & 53.23 \\
\hline Hand hoeing three times & 57.35 & 58.73 & 54.92 & 57.00 & 57.25 & 54.42 & 55.20 & 56.63 \\
\hline Untreated (control) & 45.97 & 45.61 & 43.53 & 46.04 & 47.39 & 46.05 & 45.13 & 46.19 \\
\hline Mean & 53.72 & 53.11 & 49.96 & & 54.56 & 53.11 & 50.53 & \\
\hline 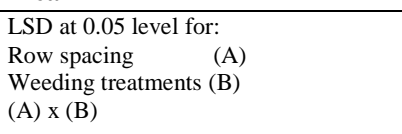 & & & & $\begin{array}{l}0.95 \\
0.96 \\
\text { NS }\end{array}$ & & & & $\begin{array}{l}0.50 \\
1.08 \\
\text { NS }\end{array}$ \\
\hline
\end{tabular}

Table (13): Sugar yield (ton/fed), as affected by row spacing, weed control treatments and their interactions in 2007/2008 and 2008/2009 seasons.

\begin{tabular}{|c|c|c|c|c|c|c|c|c|}
\hline \multirow{3}{*}{ Treatments } & \multicolumn{4}{|c|}{ 2007/2008 season } & \multicolumn{4}{|c|}{ 2008/2009 season } \\
\hline & \multicolumn{4}{|c|}{ Row spacing } & \multicolumn{4}{|c|}{ Row spacing } \\
\hline & $\begin{array}{l}\mathbf{8 0} \\
\mathrm{Cm}\end{array}$ & $\begin{array}{l}100 \\
\mathrm{~cm}\end{array}$ & $\begin{array}{l}120 \\
\mathrm{~cm}\end{array}$ & Mean & $\begin{array}{l}80 \\
\text { cm }\end{array}$ & $\begin{array}{l}100 \\
\text { cm }\end{array}$ & $\begin{array}{l}120 \\
\mathrm{~cm}\end{array}$ & Mean \\
\hline Garlon & 6.00 & 6.25 & 5.50 & 5.92 & 6.37 & 6.33 & 5.83 & 6.18 \\
\hline Brominal & 6.06 & 6.11 & 5.43 & 5.87 & 6.22 & 6.25 & 5.75 & 6.07 \\
\hline Bazagran & 5.89 & 5.86 & 5.20 & 5.65 & 6.04 & 5.88 & 5.60 & 5.84 \\
\hline Granstar & 5.69 & 5.80 & 5.33 & 5.61 & 5.85 & 5.79 & 5.53 & 5.72 \\
\hline Garlon and hand hoeing once & 6.60 & 6.42 & 5.96 & 5.33 & 6.58 & 6.51 & 6.14 & 6.41 \\
\hline Brominal and hand hoeing once & 6.60 & 6.63 & 6.22 & 6.48 & 6.60 & 6.86 & 6.32 & 6.59 \\
\hline Bazagran and hand hoeing once & 6.21 & 6.22 & 5.49 & 5.97 & 6.51 & 6.47 & 5.89 & 6.29 \\
\hline Granstar and hand hoeing once & 6.23 & 6.29 & 5.64 & 6.06 & 6.57 & 6.13 & 5.71 & 6.13 \\
\hline Hand hoeing three times & 6.46 & 6.84 & 6.39 & 6.57 & 6.84 & 6.88 & 6.60 & 6.77 \\
\hline Untreated (control) & 4.06 & 4.00 & 3.61 & 3.89 & 4.12 & 4.21 & 3.93 & 4.09 \\
\hline Mean & 5.98 & 6.04 & 5.48 & & 6.17 & 6.13 & 5.73 & \\
\hline $\begin{array}{l}\text { LSD at } 0.05 \text { level for: } \\
\text { Row spacing }\end{array}$ & & & & & & & & \\
\hline $\begin{array}{l}\text { Row spacing } \\
\text { Weeding treatments (B) }\end{array}$ & & & & $\begin{array}{l}0.09 \\
0.18 \\
\text { NS }\end{array}$ & & & & $\begin{array}{l}0.14 \\
0.14\end{array}$ \\
\hline
\end{tabular}


Table (14): Gross income, total costs, net income (by Egyptian pound) and profitability as affected by row spacing, weed control treatments and their interactions in $2007 / 2008$ and $2008 / 2009$ seasons

\begin{tabular}{|c|c|c|c|c|c|c|c|}
\hline \multirow{2}{*}{$\begin{array}{c}\text { Row } \\
\text { spacing }\end{array}$} & \multirow{2}{*}{ Weed control } & \multicolumn{2}{|c|}{ Gross income L.E } & \multirow{2}{*}{ Mean } & \multirow{2}{*}{$\begin{array}{l}\text { Total } \\
\text { cost } \\
\text { L.E }\end{array}$} & \multirow{2}{*}{$\begin{array}{c}\text { Net } \\
\text { income } \\
\text { L.E }\end{array}$} & \multirow{2}{*}{$\begin{array}{l}\text { Profitabil } \\
\text { ity }(\%)\end{array}$} \\
\hline & & $2007 / 2008$ & $2008 / 2009$ & & & & \\
\hline \multirow{10}{*}{$80 \mathrm{~cm}$} & Garlon & 12519.96 & 13169.52 & 12844.74 & 7070 & 5774.74 & 81.68 \\
\hline & Brominal & 12609.07 & 12733.35 & 12671.21 & 7040 & 5631.21 & 79.98 \\
\hline & Bazagran & 12339.39 & 12461.33 & 12400.36 & 7030 & 5370.36 & 76.39 \\
\hline & Granstar & 12001.71 & 12043.92 & 12022.82 & 6990 & 5032.82 & 72.00 \\
\hline & Garlon and hand hoeing once & 13263.32 & 13293.81 & 13278.56 & 7250 & 6028.56 & 83.15 \\
\hline & Brominal and hand hoeing once & 13258.63 & 13249.25 & 13253.94 & 7220 & 6033.94 & 83.57 \\
\hline & Bazagran and hand hoeing once & 12782.60 & 13195.32 & 12988.96 & 7210 & 5778.96 & 80.15 \\
\hline & Granstar and hand hoeing once & 12984.27 & 13253.94 & 13119.10 & 7170 & 5949.10 & 82.97 \\
\hline & Hand hoeing three times & 13448.58 & 13425.13 & 13436.85 & 7490 & 5946.85 & 79.40 \\
\hline & Untreated (control) & 10779.97 & 11112.96 & 10946.46 & 6950 & 3996.46 & 57.50 \\
\hline \multicolumn{2}{|l|}{ Mean } & 12597.34 & 12794.32 & 12695.83 & 7142 & 5553.83 & 77.76 \\
\hline \multirow{10}{*}{$100 \mathrm{~cm}$} & Garlon & 12580.93 & 12850.60 & 12715.76 & 7070 & 5645.76 & 79.85 \\
\hline & Brominal & 12294.84 & 12337.05 & 12315.94 & 7040 & 5275.94 & 74.94 \\
\hline & Bazagran & 12135.38 & 11987.64 & 12061.51 & 7030 & 5031.51 & 71.57 \\
\hline & Granstar & 11764.87 & 11825.84 & 11795.35 & 6990 & 4805.35 & 68.75 \\
\hline & Garlon and hand hoeing once & 12864.67 & 12766.18 & 12815.43 & 7250 & 5565.43 & 76.76 \\
\hline & Brominal and hand hoeing once & 13286.77 & 13268.01 & 13277.39 & 7220 & 6057.39 & 83.90 \\
\hline & Bazagran and hand hoeing once & 12590.31 & 12799.01 & 12694.66 & 7210 & 5484.66 & 76.07 \\
\hline & Granstar and hand hoeing once & 12566.86 & 12440.23 & 12503.54 & 7170 & 5333.54 & 74.39 \\
\hline & Hand hoeing three times & 13772.19 & 12761.49 & 13266.84 & 7490 & 5776.84 & 77.127 \\
\hline & Untreated (control) & 10695.55 & 10798.73 & 10747.14 & 6950 & 3797.14 & 54.64 \\
\hline \multicolumn{2}{|l|}{ Mean } & 12454.30 & 12454.30 & 12454.30 & 7142 & 5312.30 & 74.38 \\
\hline \multirow{10}{*}{$120 \mathrm{~cm}$} & Garlon & 11732.04 & 11952.47 & 11842.25 & 7070 & 4772.25 & 67.50 \\
\hline & Brominal & 11544.44 & 11706.24 & 11625.34 & 7040 & 4585.34 & 65.13 \\
\hline & Bazagran & 11103.58 & 11509.26 & 11306.42 & 7030 & 4276.42 & 60.84 \\
\hline & Granstar & 11183.31 & 11335.73 & 11259.52 & 6990 & 4269.52 & 61.08 \\
\hline & Garlon and hand hoeing once & 12311.25 & 12107.24 & 12209.24 & 7250 & 4959.24 & 68.40 \\
\hline & Brominal and hand hoeing once & 12714.59 & 12562.17 & 12638.38 & 7220 & 5418.38 & 75.05 \\
\hline & Bazagran and hand hoeing once & 11619.48 & 12027.51 & 11823.49 & 7210 & 4613.49 & 63.99 \\
\hline & Granstar and hand hoeing once & 11872.74 & 11753.14 & 11812.94 & 7170 & 4642.94 & 64.76 \\
\hline & Hand hoeing three times & 12878.74 & 12944.40 & 12911.57 & 7490 & 5421.57 & 72.38 \\
\hline & Untreated (control) & 10207.79 & 10582.99 & 10395.39 & 6950 & 3445.39 & 49.57 \\
\hline \multicolumn{2}{|l|}{ Mean } & 11715.62 & 11849.29 & 11782.45 & 7142 & 4640.45 & 64.97 \\
\hline \multirow{10}{*}{$\begin{array}{c}\text { Mean of } \\
\text { weed } \\
\text { control }\end{array}$} & Garlon & 12278.42 & 12658.31 & 12468.37 & 7070 & 5398.37 & 76.35 \\
\hline & Brominal & 12149.45 & 12259.66 & 12204.55 & 7040 & 5164.55 & 73.36 \\
\hline & Bazagran & 11858.67 & 11985.30 & 11921.98 & 7030 & 4891.98 & 69.59 \\
\hline & Granstar & 11649.96 & 11736.73 & 11693.34 & 6990 & 4703.34 & 67.29 \\
\hline & Garlon and hand hoeing once & 12813.08 & 12723.97 & 12768.53 & 7250 & 5518.53 & 76.12 \\
\hline & Brominal and hand hoeing once & 13085.10 & 13026.48 & 13055.79 & 7220 & 5835.79 & 80.83 \\
\hline & Bazagran and hand hoeing once & 12330.01 & 12674.73 & 12502.37 & 7210 & 5292.37 & 73.40 \\
\hline & Granstar and hand hoeing once & 12475.40 & 12482.44 & 12478.92 & 7170 & 5308.92 & 74.04 \\
\hline & Hand hoeing three times & 13366.50 & 13279.74 & 13323.12 & 7490 & 5833.12 & 77.88 \\
\hline & Untreated (control) & 10796.38 & 10831.56 & 10813.97 & 6950 & 3863.97 & 55.60 \\
\hline
\end{tabular}


In conclusion, growing sugarcane, under conditions of the present work, in rows spaced at 80 or $100 \mathrm{~cm}$ and controlling accompanied weeds by manual hoeing three times 25, 45 and 65 DAP, Brominal + hand hoeing once and/or Garlon + hand hoeing once, can be recommended for getting the highest cane and sugar yields/fed. Meanwhile, economic evaluation of the studied factors showed that planting sugarcane in rows of $80-\mathrm{cm}$ apart, as well as controlling weeds by applying Brominal herbicide + hand hoeing once or manual hoeing three times gave the highest values of net income and profitability\%.

\section{REFERENCES}

Ahmed A.Z. and Khaled K.A.M. (2008). Marker assisted selection for yield and some quality traits of sugarcane genotypes under different row spacing. Minia J. Agric. Res. Develop. 28 (4):585-606.

Ali A.D., Reagan T.E., Kitchen L.M. and Flynn J.L. (1986). Effects of Johnson grass (Sorghum halepense) density on sugarcane (Saccharum officinarum) yield. Weed Sci. 34: 381-383.

Association of Official Agricultural Chemist (1995). Official methods of analysis. AOAC, Box 540, Washington.

Attalla S.I. and El-SogheirK.S. (2003). Effect of weed control treatments and $\mathrm{N}$ fertilizer levels on weeds and sugarcane (Saccharum sp.) Bulletin Fac. Agric., Cairo. Univ., 54 (3): 371382.

Avtar S., Rajbahadur S., Singh A. and Singh R. (2001). Effect of agronomic practices on the productivity of late planted sugarcane. Crop Res. Hisar., 21 (2): 123-125.

Buckett M. (1981). An Introduction to Farm Organization and Management. Pergamon Press Ltd. England Ed.2.

Chang J. H. (1974). Radiation Distribution Within the Plant Community: 36-42. Climate and Agriculture, Aldine Publishing Company, Chicago, Illinois, USA.

El-Geddawy I.H., Darweish D.G., El-Sherbiny A.A. and El-Hady E.E.A. (2002-a). Effect of row spacing and number of buds/seed setts on: 3. Yield components of ratoon crops for some sugar cane varieties ratoon. Pakistan Sugar J., 17 (2): 2-8.

El-Geddawy I.H., Darweish D.G., El-Sherbiny A.A. and El-Hady E.E.A. (2002-b). Effect of row spacing and number of buds/seed setts on: 1. Growth characters of ratoon crops for some sugar cane varieties. Pakistan Sugar J., 17 (3): 7-14.
El-Shafai A.M.A. and Ismail A.M.A. (2006). Effect of row spacing on yield and quality of some promising sugarcane varieties. Egypt J. Appl. Sci., 21 (11): 32-46.

Fakkar A.A.O., Ibrahim M.M. and Bekheet M.A. (2009). Effect of some weed control methods on yield and quality of sugarcane under Sohag conditions. J. Agric. Sci. Mansoura Univ., 34 (2): 901-911.

Ibrahim A.A.S. (1984). Weed competition and control in sugarcane. Weed Res., 24: 227-232.

Manuel R.I. and Panneerselvam P. (2005). Effect of nutrient levels and herbicides on weeds and sugarcane. Indian. J. Weed-Sci., 37 (1/2): 114116.

Mohamed B.D. and Ismail A.M.A. (2002). Response of three sugarcane varieties to varying inter-row spacing and application time of nitrogen fertilizer. Egypt. J. Appl. Sci; 17 (2): 102-116.

Raskar B.S. and Bhoi P.G. (2003). Yield attributes of sugarcane as influenced by intra-row spacings, fertilizer levels and planting materials. Indian Sugar, 53 (5): 327-331.

Raskar B.S. (2004). Evaluation of herbicides for weed control in sugarcane. Sugar Technol., 6 (3):173-175.

Rizk T.Y., El-Agroudy M.H., El-Geddawy I.H. and Fergany M.A. (2004-a). Effect of row spacing and cutting size on cane juice quality attributes. Egypt. J. Agric. Res., 82 (1): 251262.

Rizk T.Y., El-Agroudy M.H., El-Geddawy I.H. and Fergany M.A. (2004-b). Effect of row distance and cutting size on growth criteria of two promising sugar cane varieties and the commercial variety. Egypt. J. Agric. Res., 82 (1): 263-276.

Saini L.K., Aggarwal N. and Bhullar M.S. (2003). Chemical weed control in spring planted sugarcane. Indian J. Sugarcane Technol., 18 (1/2): 101-103.

Singh A., Virk A.S. and Singh J. (2001). Efficacy of a new herbicide for the control of weeds in sugarcane. Sugar Technol. 3 (1 and 2): 63-64.

Singh A and Kaur C. (2003). Evaluation of herbicides for the control of weeds in spring planted sugarcane. Sugar Technol. 5 (4): 317318.

Singh A.K., Menhi L.A.L. and Prasad S.R. (2006). Effect of row spacing and nitrogen on ratoon ability of early maturing high sugar genotypes of sugarcane (Saccharum spp.) hybrids. Indian J. Agric. Sci., 76 (2):108-110.

Singh A.K. and Menhi L.A.L. (2008). Weed management in spring planted sugarcane 